Review

\title{
Medicinal Plants: A Source of Anti-Parasitic Secondary Metabolites
}

\author{
Michael Wink \\ Institute of Pharmacy and Molecular Biotechnology, INF 364, Heidelberg University, \\ D-69120 Heidelberg, Germany; E-Mail: wink@uni-hd.de; Tel.: +49-6221-544881; \\ Fax: +49-06221-544884
}

Received: 12 September 2012; in revised form: 19 October 2012 / Accepted: 26 October 2012 / Published: 31 October 2012

\begin{abstract}
This review summarizes human infections caused by endoparasites, including protozoa, nematodes, trematodes, and cestodes, which affect more than $30 \%$ of the human population, and medicinal plants of potential use in their treatment. Because vaccinations do not work in most instances and the parasites have sometimes become resistant to the available synthetic therapeutics, it is important to search for alternative sources of anti-parasitic drugs. Plants produce a high diversity of secondary metabolites with interesting biological activities, such as cytotoxic, anti-parasitic and anti-microbial properties. These drugs often interfere with central targets in parasites, such as DNA (intercalation, alkylation), membrane integrity, microtubules and neuronal signal transduction. Plant extracts and isolated secondary metabolites which can inhibit protozoan parasites, such as Plasmodium, Trypanosoma, Leishmania, Trichomonas and intestinal worms are discussed. The identified plants and compounds offer a chance to develop new drugs against parasitic diseases. Most of them need to be tested in more detail, especially in animal models and if successful, in clinical trials.
\end{abstract}

Keywords: protozoa; parasites; medicinal plants; secondary metabolites; molecular targets

\section{Introduction}

During the evolution of humans a broad set of parasites have evolved, that use us as a host organism. Usually a parasite will not kill its host (at least not immediately), as this would by an evolutionary dead end for a parasite. However, most parasites are either unpleasant for us (think of lice and fleas) or weaken our health (most internal parasites). However, some parasitic infections, such as 
malaria, trypanosomiasis or Chagas can be deadly if the patients are not treated with adequate therapeutics. Because humans usually live in close proximity and often without good hygienic conditions the transmission of parasites within a human population is often facilitated.

It is very likely that humans have always tried to get rid or minimize the impact of parasites. External parasites (ectoparasites) could be reduced or eliminated mechanically. This could be done individually or in groups. Grooming is a common behaviour in primates and monkeys delouse each other in consequence. Humans probably did the same. More complicated to treat were internal parasites (endoparasites). We know that humans have used medicinal plants for several thousands of years to treat illness and health disorders [1]. It is likely that humans also identified plants which were useful as antiparasitic drugs. Even today, infections by parasites are often treated by plant products or secondary metabolites isolated from them. Circumstantial evidence suggests that chimpanzees, our closest primate relatives, selectively eat medicinal plants when suffering from infections.

Unfortunately, infections by endoparasites can hardly be prevented by vaccination. Even for malaria, one of the most common parasitic diseases which infects over 200-300 million people and kills more than 1 million per year, an effective vaccine is not (yet) available because the parasites have clever strategies to outcompete our immune system, for example by continuously changing their surface coatings.

Medicinal chemists have synthesized a number of drugs which can be used against many but by far not all endoparasites. A major problem is that many of these drugs were developed many years ago and some parasitic strains have become resistant to them. The development of new antiparasitic drugs has not been much of a priority for the pharmaceutical industry because many of the parasitic diseases occur in poor countries where the populations cannot afford to pay a high price for the drugs. Thus an investment in drug development against parasitic diseases is a risky affair.

An alternative to synthetic drugs is the search for anti-parasitic plant extracts or secondary metabolites derived from them. Natural products still play an important role in therapy: between 1981 and 2006, 1,184 new drugs were registered of which 28\% were natural products or their derivatives. Another $24 \%$ of the new drugs had pharmacophores (i.e., functional groups with pharmacological activity) derived from natural products [2]. A good starting point to find antiparasitic natural products would be traditional medicinal plants, such as those known from Asia, Africa or America [1] that have been employed to treat infections.

Many promising results have been obtained so far to kill the parasites or their vectors in vitro, however a translation of these results into clinical practice is a neglected field. In this review, special focus will be on medicinal plants used in traditional medicine against parasitic infections. It is out of scope of this review to mention all the natural products individually that have been tested and which exhibit some sort of antiparasitic activity. If available, references to more specific reviews are provided. Furthermore, tropical diseases caused by viruses, bacteria and fungi will not be addressed in this review although plant-derived drugs can provide interesting candidates for therapy [3].

\section{Human Parasites and Parasitic Diseases}

Many parasitic infections are the cause of tropical diseases, such as malaria, trypanosomiasis, leishmaniasis, Chagas disease, schistosomiasis, onchocerciasis, lymphatic filariasis, and helminthiases. 
Parasites are responsible for probably more than 1-2 billion infections, which lead to several million deaths every year [4]. In addition to these economically important parasitic diseases, a number of ectoparasites affect human health, which include mites (Sarcoptes scabiei causing scabies), lice (Pediculus capitis; Phthirus pubis), bed bugs (Cimex lectularius, C. hemipterus), fleas (Pulex irritans, Tunga penetrans), and several myiasis-producing diptera (Chrysomya, Cochliomya, Wohlfahrtia, Sarcophaga, Dermatobia, Cuterebra, Gasterophilus, Hypoderma, Oestrus). An overview on important endoparasites, their vectors, distribution, and disease symptoms is given in Table $1[4,5]$ in order to understand the challenge which we are faced worldwide. Many human parasites are transmitted by arthropod vectors, which could also be a target for secondary metabolites with insecticidal properties [6,7].

Table 1. Examples (a selection) of important human endoparasites [4].

\begin{tabular}{|c|c|c|c|c|}
\hline Parasite & $\begin{array}{l}\text { Disease } \\
\text { (estimated } \\
\text { number of } \\
\text { infections) } \\
\end{array}$ & $\begin{array}{l}\text { Vector (hosts); } \\
\text { route of } \\
\text { transmission }\end{array}$ & Distribution & Symptoms \\
\hline \multicolumn{5}{|l|}{ Protozoa } \\
\hline \multicolumn{5}{|l|}{ Apicomplexa } \\
\hline Babesia spp. & $\begin{array}{l}\text { Piroplasmosis } \\
\text { (rare) }\end{array}$ & $\begin{array}{l}\text { Ticks (Ixodes); } \\
\text { bites }\end{array}$ & $\begin{array}{l}\text { North } \\
\text { America }\end{array}$ & Anaemia, damage of immune system \\
\hline $\begin{array}{l}\text { Plasmodium } \\
\text { (P. vivax, P. ovale, } \\
\text { P. malariae, } \\
\text { P. knowlesi, } \\
\text { P. falciparum) }\end{array}$ & $\begin{array}{l}\text { Malaria } \\
(>250 \text { million })\end{array}$ & $\begin{array}{l}\text { Mosquitos } \\
\text { (Anopheles, } \\
\text { Nyssorhynchus, } \\
\text { Cellia, Kerteszia); } \\
\text { bites }\end{array}$ & $\begin{array}{l}\text { Tropics and } \\
\text { subtropics }\end{array}$ & $\begin{array}{l}\text { Anaemia, enlarged liver and spleen, } \\
\text { high fever, jaundice, haemorrhage, } \\
\text { haemoglobinuria (“blackwater fever”); } \\
\text { blockage of cerebral capillaries } \\
\text { (P. falciparum) }\end{array}$ \\
\hline Toxoplasma gondii & Toxoplasmosis & $\begin{array}{l}\text { Main host are cats; } \\
\text { infection of } \\
\text { humans from } \\
\text { faeces }\end{array}$ & Worldwide & $\begin{array}{l}\text { Flu-like symptoms; cysts in muscle } \\
\text { and neural tissues; encephalitis, serious } \\
\text { danger for developing foetus (abortion, } \\
\text { malformations) }\end{array}$ \\
\hline \multicolumn{5}{|l|}{ Trypanosomatida } \\
\hline $\begin{array}{l}\text { Trypanosoma brucei; } \\
\text { T. b. gambiense } \\
\text { T. b. rhodesiense }\end{array}$ & $\begin{array}{l}\text { African } \\
\text { trypanosomiasis } \\
(>500,000)\end{array}$ & $\begin{array}{l}\text { Tsetse flies } \\
(\text { Glossina }) \text {; bites }\end{array}$ & $\begin{array}{l}\text { Tropical } \\
\text { Africa }\end{array}$ & $\begin{array}{l}\text { Fever, rash, lymphoadenopathy, } \\
\text { sleeping sickness (waste, comatose) }\end{array}$ \\
\hline T. b. brucei & $\begin{array}{l}\text { Nagana } \\
\text { (only cattle) }\end{array}$ & $\begin{array}{l}\text { Tsetse flies } \\
(\text { Glossina }) \text {; bites }\end{array}$ & $\begin{array}{l}\text { Tropical } \\
\text { Africa }\end{array}$ & Loss of cattle; symptoms as in humans \\
\hline Trypanosoma cruzi & $\begin{array}{l}\text { Chagas disease } \\
\text { (10 million) }\end{array}$ & $\begin{array}{l}\text { Bugs of the family } \\
\text { Reduviidae } \\
\text { (Rhodnius, } \\
\text { Triatoma, } \\
\text { Panstrongylus); } \\
\text { bites }\end{array}$ & $\begin{array}{l}\text { Central and } \\
\text { South } \\
\text { America }\end{array}$ & $\begin{array}{l}\text { Local tissue lesions of eyes (Romana's } \\
\text { sign), myocarditis, cardiomegaly, } \\
\text { megaoesophagus, megacolon }\end{array}$ \\
\hline Leishmania donovani & $\begin{array}{l}\text { Visceral } \\
\text { leishmaniasis } \\
\text { (kala-azar) } \\
\text { (15 million) }\end{array}$ & $\begin{array}{l}\text { Flies } \\
\text { (Phlebotomus, } \\
\text { Lutzomyia); bites }\end{array}$ & $\begin{array}{l}\text { N-Africa, } \\
\text { Eurasia } \\
\text { S America }\end{array}$ & $\begin{array}{l}\text { Enlargement of liver and spleen, fever, } \\
\text { dermal lesions, dermal nodules }\end{array}$ \\
\hline
\end{tabular}


Table 1. Cont.

\begin{tabular}{|c|c|c|c|c|}
\hline Parasite & $\begin{array}{l}\text { Disease } \\
\text { (estimated } \\
\text { number of } \\
\text { infections) } \\
\end{array}$ & $\begin{array}{l}\text { Vector (hosts); } \\
\text { route of } \\
\text { transmission }\end{array}$ & Distribution & Symptoms \\
\hline \multicolumn{5}{|l|}{ Trypanosomatida } \\
\hline $\begin{array}{l}\text { Leishmania tropica } \\
\text { L. major } \\
\text { L. infantum }\end{array}$ & $\begin{array}{l}\text { Cutaneous } \\
\text { leishmaniasis } \\
\text { (Old world) }\end{array}$ & Phlebotomus; bites & $\begin{array}{l}\text { Eurasia, } \\
\text { Africa }\end{array}$ & $\begin{array}{l}\text { Ulcerative lesions, mucocutaneous } \\
\text { lesions }\end{array}$ \\
\hline $\begin{array}{l}\text { Leishmania } \\
\text { mexicana and several } \\
\text { others }\end{array}$ & $\begin{array}{l}\text { Cutaneous } \\
\text { leishmaniasis } \\
\text { (New world) }\end{array}$ & Lutzomyia; bites & $\begin{array}{l}\text { Central and } \\
\text { Southern } \\
\text { America }\end{array}$ & $\begin{array}{l}\text { Ulcerative lesions, mucocutaneous } \\
\text { lesions }\end{array}$ \\
\hline \multicolumn{5}{|l|}{ Amoebida } \\
\hline $\begin{array}{l}\text { Entamoeba } \\
\text { histolytica and other } \\
\text { species }\end{array}$ & $\begin{array}{l}\text { Amoebiasis } \\
(70,000 \\
\text { deaths/year) }\end{array}$ & $\begin{array}{l}\text { Infection from } \\
\text { contaminated } \\
\text { water or food }\end{array}$ & Worldwide & $\begin{array}{l}\text { Dysentery, destruction of intestinal } \\
\text { tissues, fever, liver and lung abscess }\end{array}$ \\
\hline \multicolumn{5}{|l|}{ Diplomonadida } \\
\hline Giardia lamblia & $\begin{array}{l}\text { Giardiasis } \\
(2 \text { million } \\
\text { infections/year } \\
\text { in USA) }\end{array}$ & $\begin{array}{l}\text { Infection from } \\
\text { contaminated } \\
\text { water }\end{array}$ & Worldwide & $\begin{array}{l}\text { Infection of duodenal and jejunal } \\
\text { mucosa; diarrhoea, fever }\end{array}$ \\
\hline \multicolumn{5}{|l|}{ Trichomonadida } \\
\hline $\begin{array}{l}\text { Trichomonas } \\
\text { vaginalis } \\
\text { Trichomonas } \\
\text { hominis }\end{array}$ & $\begin{array}{l}\text { Trichomoniasis } \\
(180 \text { million each } \\
\text { year) }\end{array}$ & $\begin{array}{l}\text { Sexual } \\
\text { transmission }\end{array}$ & Worldwide & Mucosal tissue of genital tract \\
\hline \multicolumn{5}{|l|}{ METAZOA } \\
\hline \multicolumn{5}{|l|}{ Nematoda } \\
\hline \multicolumn{5}{|l|}{ Filarioidea } \\
\hline $\begin{array}{l}\text { Wucheria bancrofti } \\
\text { Brugia spp. } \\
\text { Mansonella spp. }\end{array}$ & $\begin{array}{l}\text { Lymphatic } \\
\text { filariases, } \\
\text { elephantiasis } \\
\text { (120 million) }\end{array}$ & $\begin{array}{l}\text { Mosquitos (Aedes, } \\
\text { Culex, Mansonia); } \\
\text { bites }\end{array}$ & $\begin{array}{l}\text { Tropical } \\
\text { Africa, Asia, } \\
\text { America }\end{array}$ & $\begin{array}{l}\text { Infection of lymphatic system; } \\
\text { enlargement of lymph nodes }\end{array}$ \\
\hline Loa loa & $\begin{array}{l}\text { Loaiasis } \\
\text { ( } 33 \text { million) }\end{array}$ & Chrysops & $\begin{array}{l}\text { Central } \\
\text { Africa }\end{array}$ & $\begin{array}{l}\text { Female worms migrate through tissues } \\
\text { and the eye }\end{array}$ \\
\hline Onchocerca volvulus & $\begin{array}{l}\text { Skin filariases; } \\
\text { onchocerciasis; } \\
\text { river blindness } \\
\text { (>17 million) }\end{array}$ & $\begin{array}{l}\text { Flies } \\
\text { (Simulium spp.); } \\
\text { bites }\end{array}$ & $\begin{array}{l}\text { Mostly } \\
\text { tropical } \\
\text { Africa and } \\
\text { America } \\
\end{array}$ & $\begin{array}{l}\text { Formation of large nodules under skin } \\
\text { or in eyes (causing blindness) }\end{array}$ \\
\hline \multicolumn{5}{|l|}{ Trichuroidea } \\
\hline Trichinella spiralis & $\begin{array}{l}\text { Trichinosis } \\
\text { (50 million) }\end{array}$ & $\begin{array}{l}\text { Eating of infected } \\
\text { muscles e.g., from } \\
\text { pigs; bites }\end{array}$ & Worldwide & $\begin{array}{l}\text { Invades muscular tissue, fever, } \\
\text { myalgia, malaise and oedema }\end{array}$ \\
\hline Trichurus trichiura & (500 million) & $\begin{array}{l}\text { Infection from } \\
\text { contaminated soil }\end{array}$ & Worldwide & Intestinal infection \\
\hline
\end{tabular}


Table 1. Cont.

\begin{tabular}{|c|c|c|c|c|}
\hline Parasite & $\begin{array}{l}\text { Disease } \\
\text { (estimated } \\
\text { number of } \\
\text { infections) } \\
\end{array}$ & $\begin{array}{l}\text { Vector (hosts); } \\
\text { route of } \\
\text { transmission }\end{array}$ & Distribution & Symptoms \\
\hline \multicolumn{5}{|l|}{ Rhabditoidea } \\
\hline $\begin{array}{l}\text { Strongyloides } \\
\text { stercoralis }\end{array}$ & $\begin{array}{l}\text { Strongyloidiasis } \\
\text { ( } 70 \text { million) }\end{array}$ & $\begin{array}{l}\text { Infection from } \\
\text { contaminated soil }\end{array}$ & $\begin{array}{l}\text { Subtropics, } \\
\text { tropics } \\
\text { worldwide }\end{array}$ & $\begin{array}{l}\text { Intestinal infection, anaemia; migrating } \\
\text { larvae in skin }\end{array}$ \\
\hline \multicolumn{5}{|l|}{ Ancylostomatoidea } \\
\hline $\begin{array}{l}\text { Ancylostoma } \\
\text { duodenale; } \\
\text { Necator americanus }\end{array}$ & $\begin{array}{l}\text { Hookworm } \\
\text { infection } \\
\text { (700-900 } \\
\text { million) } \\
\end{array}$ & $\begin{array}{l}\text { Infection from } \\
\text { contaminated soil }\end{array}$ & $\begin{array}{l}\text { Subtropics, } \\
\text { tropics } \\
\text { worldwide }\end{array}$ & $\begin{array}{l}\text { Intestinal infection, anaemia, migrating } \\
\text { larvae in skin }\end{array}$ \\
\hline \multicolumn{5}{|l|}{ Oxyuroidea } \\
\hline $\begin{array}{l}\text { Enterobius } \\
\text { vermicularis }\end{array}$ & $\begin{array}{l}\text { Thread or } \\
\text { pinworm } \\
\text { (400 million) }\end{array}$ & $\begin{array}{l}\text { Infection from } \\
\text { contaminated } \\
\text { humans }\end{array}$ & Worldwide & Intestinal infection \\
\hline \multicolumn{5}{|l|}{ Ascaridoidea } \\
\hline Ascaris lumbricoides & $\begin{array}{l}\text { Ascariasis } \\
(800-1000 \\
\text { million })\end{array}$ & $\begin{array}{l}\text { Infection from } \\
\text { contaminated soil }\end{array}$ & Worldwide & $\begin{array}{l}\text { Intestinal infection, migrating larvae in } \\
\text { various tissues }\end{array}$ \\
\hline \multicolumn{5}{|l|}{ Dracunculoidea } \\
\hline $\begin{array}{l}\text { Dracunculus } \\
\text { medinensis }\end{array}$ & $\begin{array}{l}\text { Dracunculiasis; } \\
\text { guinea worm } \\
\text { infection } \\
\text { (<3 million) }\end{array}$ & $\begin{array}{l}\text { Copepods as } \\
\text { intermediate host }\end{array}$ & Africa, Asia & $\begin{array}{l}\text { Infects skin; female worms can reach a } \\
\text { length of } 100 \mathrm{~cm}\end{array}$ \\
\hline \multicolumn{5}{|l|}{$\begin{array}{l}\text { Plathelmintes } \\
\text { Trematoda }\end{array}$} \\
\hline \multicolumn{5}{|l|}{ Schistosomatoidea } \\
\hline $\begin{array}{l}\text { Schistosoma mansoni } \\
\text { S. japonicum }\end{array}$ & $\begin{array}{l}\text { Schistosomiasis } \\
\text { (200 million) }\end{array}$ & $\begin{array}{l}\text { Water snails as } \\
\text { intermediate host }\end{array}$ & $\begin{array}{l}\text { Tropical and } \\
\text { subtropical } \\
\text { Africa, } \\
\text { S America } \\
\text { and E Asia }\end{array}$ & $\begin{array}{l}\text { Dermatitis, infects liver, granuloma } \\
\text { formation in liver, liver fibrosis, } \\
\text { enlarged spleen }\end{array}$ \\
\hline S. haematobium & $\begin{array}{l}\text { Schistosomiasis } \\
(80 \text { million })\end{array}$ & $\begin{array}{l}\text { Water snails as } \\
\text { intermediate host }\end{array}$ & Africa & Infection of bladder, haematuria \\
\hline \multicolumn{5}{|l|}{ Echinostomatoidea } \\
\hline $\begin{array}{l}\text { Fasciola hepatica } \\
\text { F. gigantica }\end{array}$ & $\begin{array}{l}\text { Fasciolopsiasis } \\
(2.4 \text { million })\end{array}$ & $\begin{array}{l}\text { Water snail } \\
(\text { Lymnaea }) \text { as host }\end{array}$ & Worldwide & Infection of liver \\
\hline \multicolumn{5}{|l|}{ Opisthorchioidea } \\
\hline $\begin{array}{l}\text { Opisthorchis felineus } \\
\text { O. viverrini }\end{array}$ & $\begin{array}{l}\text { Opisthorchiasis, } \\
\text { liver fluke } \\
\text { (10 million) }\end{array}$ & $\begin{array}{l}\text { Water snails as } \\
\text { intermediate host; } \\
\text { infection from } \\
\text { infected fish }\end{array}$ & $\begin{array}{l}\text { E Europe, } \\
\text { Central and } \\
\text { Eastern Asia }\end{array}$ & Infection of liver and gall bladder \\
\hline
\end{tabular}


Table 1. Cont.

\begin{tabular}{|c|c|c|c|c|}
\hline Parasite & $\begin{array}{l}\text { Disease } \\
\text { (estimated } \\
\text { number of } \\
\text { infections) }\end{array}$ & $\begin{array}{l}\text { Vector (hosts); } \\
\text { route of } \\
\text { transmission }\end{array}$ & Distribution & Symptoms \\
\hline \multicolumn{5}{|l|}{ Opisthorchioidea } \\
\hline $\begin{array}{l}\text { O. sinensis } \\
\text { (syn. Clonorchis) }\end{array}$ & $\begin{array}{l}\text { Clonorchiasis } \\
\text { (35 million) }\end{array}$ & $\begin{array}{l}\text { Water snails as } \\
\text { intermediate host; } \\
\text { infection from } \\
\text { infected fish }\end{array}$ & China, Japan & Infection of liver, fibrosis, carcinoma \\
\hline \multicolumn{5}{|l|}{ Plagiorchioidea } \\
\hline $\begin{array}{l}\text { Paragoniumus } \\
\text { westermani } \\
\text { P. mexicanus and } \\
\text { other species }\end{array}$ & $\begin{array}{l}\text { Paragonimiasis } \\
\text { (20 million) }\end{array}$ & $\begin{array}{l}\text { Water snails and } \\
\text { craps as } \\
\text { intermediate hosts; } \\
\text { infection from } \\
\text { infected meat }\end{array}$ & $\begin{array}{l}\text { Tropics of } \\
\text { Africa, } \\
\text { America and } \\
\text { E Asia }\end{array}$ & $\begin{array}{l}\text { Infection of internal organs, including } \\
\text { lungs and brain }\end{array}$ \\
\hline \multicolumn{5}{|l|}{$\begin{array}{l}\text { Platyhelminthes/ } \\
\text { Cestoda }\end{array}$} \\
\hline $\begin{array}{l}\text { Diphyllobothrium } \\
\text { latum and other } \\
\text { cestodes }\end{array}$ & $\begin{array}{l}\text { Diphyllobo- } \\
\text { thriasis (fish } \\
\text { tapeworm) } \\
\text { (16 million) }\end{array}$ & $\begin{array}{l}\text { Infection from } \\
\text { infected fish }\end{array}$ & Worldwide & Intestinal infection; Vit B12 deficiency \\
\hline Dipylidium caninum & $\begin{array}{l}\text { Dog tapeworm } \\
\text { (rare) }\end{array}$ & $\begin{array}{l}\text { Dogs and cats are } \\
\text { main hosts; fleas } \\
\text { intermediate hosts } \\
\text { which can infect } \\
\text { humans; bites }\end{array}$ & Worldwide & Intestinal infection \\
\hline $\begin{array}{l}\text { Vampirolepis nana } \\
\text { (syn. Hymenolepis) }\end{array}$ & $\begin{array}{l}\text { Dwarf tapeworm } \\
\text { (36 million) }\end{array}$ & $\begin{array}{l}\text { Rodents are main } \\
\text { hosts; insects } \\
\text { intermediate hosts; } \\
\text { bites }\end{array}$ & Worldwide & Intestinal infection \\
\hline $\begin{array}{l}\text { Taenia solium } \\
\text { T. asiatica } \\
\text { T. saginata }\end{array}$ & $\begin{array}{l}\text { Pork and beef } \\
\text { tapeworm } \\
\text { (80 million) }\end{array}$ & $\begin{array}{l}\text { Infection from } \\
\text { contaminated meat }\end{array}$ & Worldwide & $\begin{array}{l}\text { Intestinal infection; cysts in various } \\
\text { tissues (including brain) }\end{array}$ \\
\hline $\begin{array}{l}\text { Echinococcus } \\
\text { granulosus } \\
\text { E. multilocularis }\end{array}$ & $\begin{array}{l}\text { Hydatidosis, } \\
\text { echinococcosis } \\
\text { (thousands) }\end{array}$ & $\begin{array}{l}\text { Dogs, foxes; } \\
\text { Infection from } \\
\text { faeces }\end{array}$ & Worldwide & $\begin{array}{l}\text { Cyst (hydatid) formation in liver, lung } \\
\text { or brain }\end{array}$ \\
\hline
\end{tabular}

\section{Antiparasitic Medicinal Plants and Their Secondary Metabolites}

Parasites are eukaryotes and therefore share most molecular and biochemical properties with their eukaryotic hosts, making it often difficult to find antiparasitic drugs which are both effective and non-toxic for humans. This limitation always has to be kept in mind when discussing the numerous findings that some drug or extract from a medicinal plant is active against parasites in vitro. In order to be medicinally useful, such a drug must have bioavailability and should not intoxicate the patient. A 
first guidance is the determination of a selectivity index (SI) which compares the cytotoxicity of a drug against a parasite and a library of human cells.

\subsection{Mode of Action of Antiparasitic Cytotoxic Drugs}

A number of general cellular targets exists which can mediate cytotoxicity in human cells but also in parasites [8]. Major targets include: (1) DNA, RNA. (2) Proteins of the cytoskeleton. (3) Biomembranes.

\subsubsection{DNA, RNA}

Compounds which damage DNA often have cytotoxic and antiparasitic properties. Typical DNA damage occurs when DNA alkylating compounds form covalent bonds with DNA bases. If these alkylations are not reversed by DNA repair enzymes, problems will occur after the next round of replication. Consequences are point mutations, and sometimes deletions and frame-shift mutations. If such mutations occur in important protein coding genes, they can lead to the death of a parasite. Typical DNA alkylating compounds which are found in medicinal plants include aristolochic acid (in Aristolochia), cycasin (in Cycadaceae), furanoquinoline alkaloids (in several species of Rutaceae), furanocoumarins (in many Apiaceae, Fabaceae), pyrrolizidine alkaloids (in Boraginaceae, Crotalarieae, Asteraceae), ptaquiloside (in Pteridium aquilinum) (Figure 1) and secondary metabolites (SM) with an epoxide as a functional group $[9,10]$.

Another group of DNA damaging compounds intercalates DNA. These compounds are usually aromatic, planar and hydrophobic so that they can intercalate between the planar stacks of nucleotide pairs, especially GC-pairs. DNA intercalating compounds stabilize the DNA double helix and impair the replication process. Typical mutations which are caused by them are frame-shift mutations and deletions. These mutations usually lead to cell death [8]. Typical DNA intercalating compounds are common in the group of protoberberine and benzophenanthridine alkaloids, such as berberine and sanguinarine [10,11]. Many of the plants which produce such alkaloids (families Papaveraceae, Berberidaceae, Menispermaceae, Ranunculaceae) are known for their antiparasitic, antimicrobial, and antiviral properties. Intercalating alkaloids have also been detected among quinoline alkaloids (such as quinine), furanoquinoline alkaloids (Rutaceae), emetine (Cephaelis acuminata, Rubiaceae), beta-carboline alkaloids (e.g., in Peganum harmala, Nitrariaceae), anthraquinones (many Polygonaceae, Rhamnaceae), and furanocoumarins (many Apiaceae, Fabaceae) [9,10] (Figure 1).

Some of the intercalating compounds inhibit the enzyme DNA topoisomerase I or II which are essential for the replication process. If DNA topoisomerases are blocked, cells cannot divide. A typical topoisomerase inhibitor would be the indole alkaloid camptothecin (CPT) from Camptotheca acuminata, Ophiorrhiza spp., Notapodytes spp., Ervatamia heyneana and Mostuea brunonis [9,10,12] (Figure 1).

Cells treated with alkylating and intercalating drugs or topoisomerase inhibitors usually undergo programmed cell death by apoptosis [8] which can also occur in unicellular protozoa [13]. 
Figure 1. Examples of secondary metabolites which alkylate or intercalate DNA.

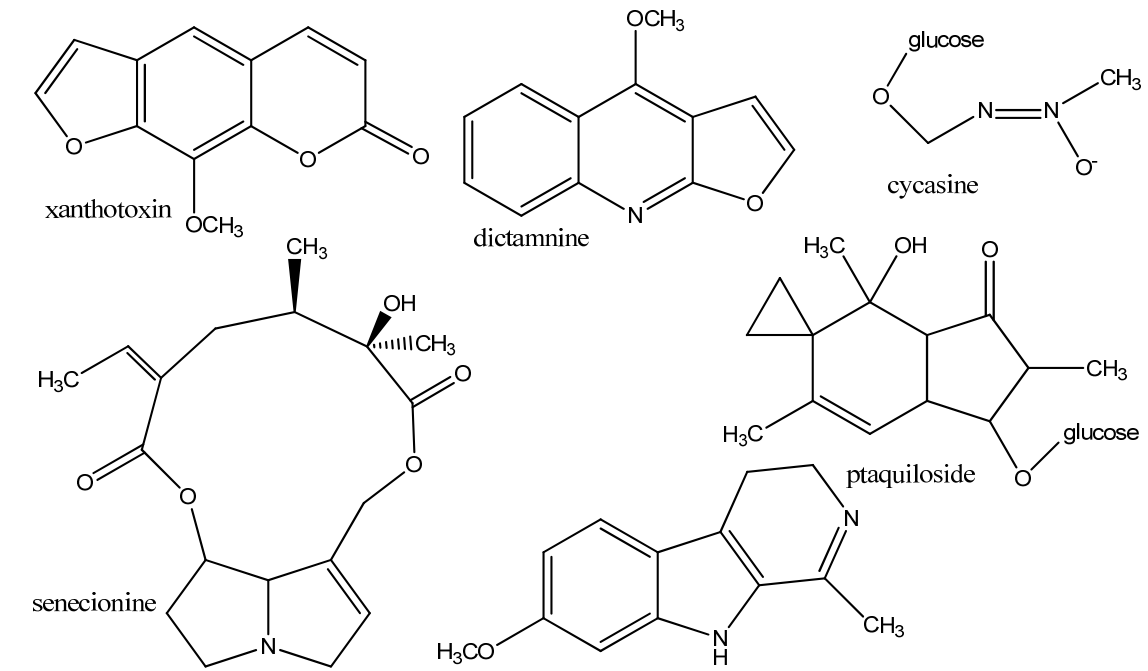

harmaline<smiles>CC[C@H]1CN2CCc3cc(OC)c(OC)cc3C2C[C@H](CC2NCCc3cc(OC)c(OC)cc32)C1c1cc2c(cc1OC)C(=O)OCc1c-2cc2n(c1=O)Cc1cc3ccccc3nc1C1=Nc3c(ccc4c3OCO4)C1=C2</smiles>

\subsubsection{Proteins of the Cytoskeleton and Enzymes}

Actin filaments and microtubules are the major proteins of the cytoskeleton of eukaryotic cells which are important for cell architecture. In addition, functional microtubules are required for the assembly of the mitotic spindle necessary for cell division. A number of natural products are known which have affinity for microtubules: some of them inhibit the polymerisation of tubulin into microtubules such as colchicine (from Colchicum spp., Gloriosa superba; Colchicaceae), vinblastine (Catharanthus roseus, Apocynaceae), podophyllotoxin (Podophyllum spp.; Berberidaceae; several Linum species; Linaceae), sanguinarine (Sanguinaria canadensis; Macleaya spp., Bocconia spp.; Papaveraceae), maytansine (Maytenus spp.; Celastraceae), rotenone (in several genera of Fabaceae, such as Derris and Lonchocarpus), chalcones, combretastatin (in Combretum caffrum; Combretaceae) 
or inhibit the depolymerisation of microtubules (such as paclitaxel from Taxus spp.; Taxaceae) (Figure 2). Some of these natural products are presently used in the chemotherapy of cancer $[8,12,14]$. Often, they have antiparasitic properties.

Figure 2. Examples of secondary metabolites which interfere with microtubule formation or disassembly.

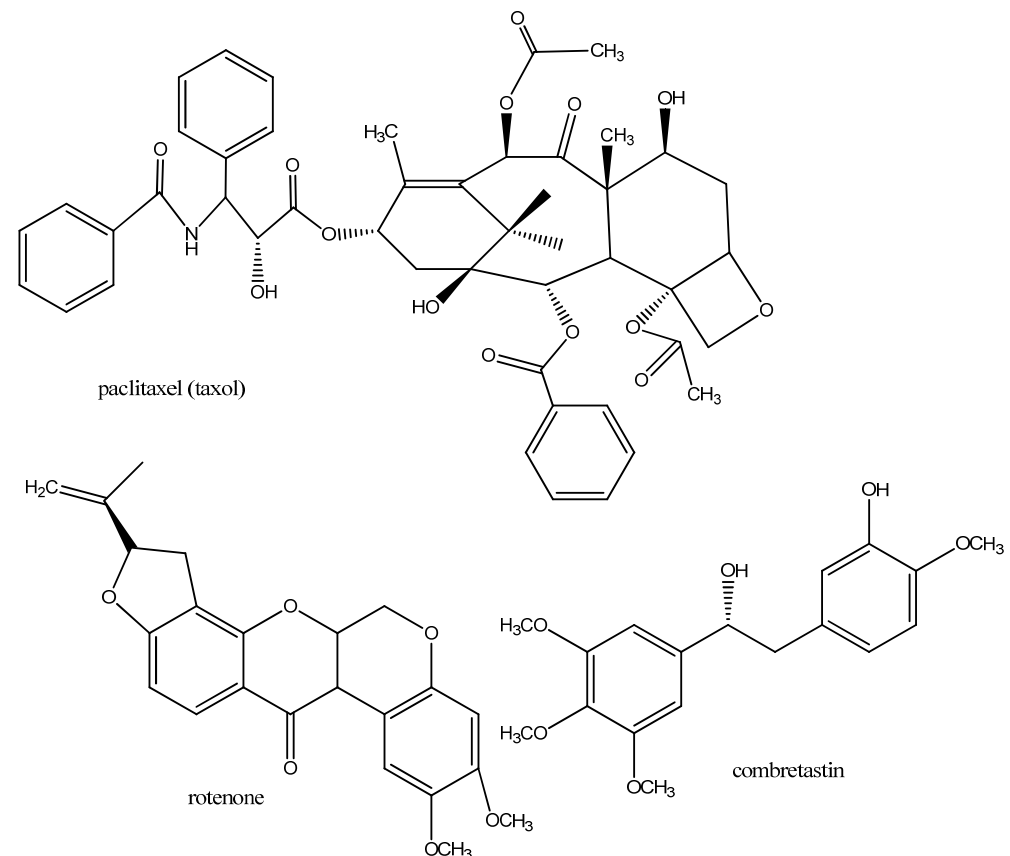<smiles>COc1ccc2c(c1)C(NC(C)=O)CCc1cc(O)c(O)c(OC)c1-2</smiles><smiles>COc1cc([C@H]2c3cc4c(cc3[C@@H](O)C3COC(=O)C32)OCO4)cc(OC)c1OC</smiles>

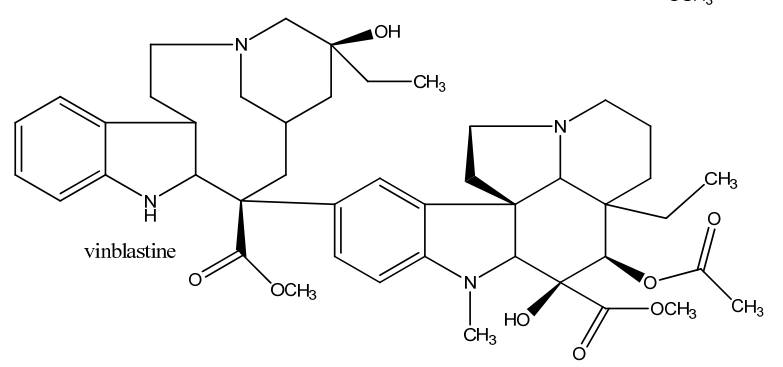<smiles>COc1cc2cc(c1Cl)N(C)[C@@H](C)C(=O)C[C@@H](N(C)C(C)=O)CC(C)[C@]1(C)OC1[C@H](C)C1C[C@](O)(NC(=O)O1)[C@H](C)/C=C/C=C(\C)C2</smiles> 
The alkaloid emetine (from Rubiaceae) not only intercalates DNA but it is a very potent inhibitor of ribosomal protein biosynthesis. The pure alkaloid is still in use to treat amoebial infections [15]. Many parasites which live in the blood or intracellularly have closely adapted to their environment. These adaptations are often biochemically unique and offer vulnerable targets (enzymes, receptors) for specific antiparasitic drugs.

\subsubsection{Biomembranes}

All living cells are surrounded by a phospholipid bilayer, the cell membrane. It functions as a permeation barrier to prevent the escape of cellular metabolites but also controls an uncontrolled entry of polar or toxic exogenous compounds. If fluidity or permeability of the biomembrane are disturbed by natural products with detergent properties (as present in the large class of widely distributed triterpenoid and steroidal saponins, which occur in more than $30 \%$ of higher plants; Figure 3) a cytotoxic or antimicrobial effect can often be observed $[9,16]$. Small lipophilic secondary metabolites, such as terpenoids or phenylpropanoids as found in the essential oil of many plants (especially in Lamiaceae, Myrtaceae, Rubiaceae, Apiaceae, Asteraceae, Lauraceae, Rutaceae, Burseraceae, Verbenaceae, Pinaceae, Cupressaceae), can dissolve in biomembranes and disturb their fluidity and the function of membrane proteins [16]. Therefore, many of the lipophilic mono- and sesquiterpenes, phenylpropanoids and isothiocyanates (as present in Brassicaceae, Tropaeoleaceae) have a certain degree of antimicrobial and antiparasitic properties [9].

Figure 3. Example for steroidal and triterpene saponins (monodesmosides with one sugar chain).

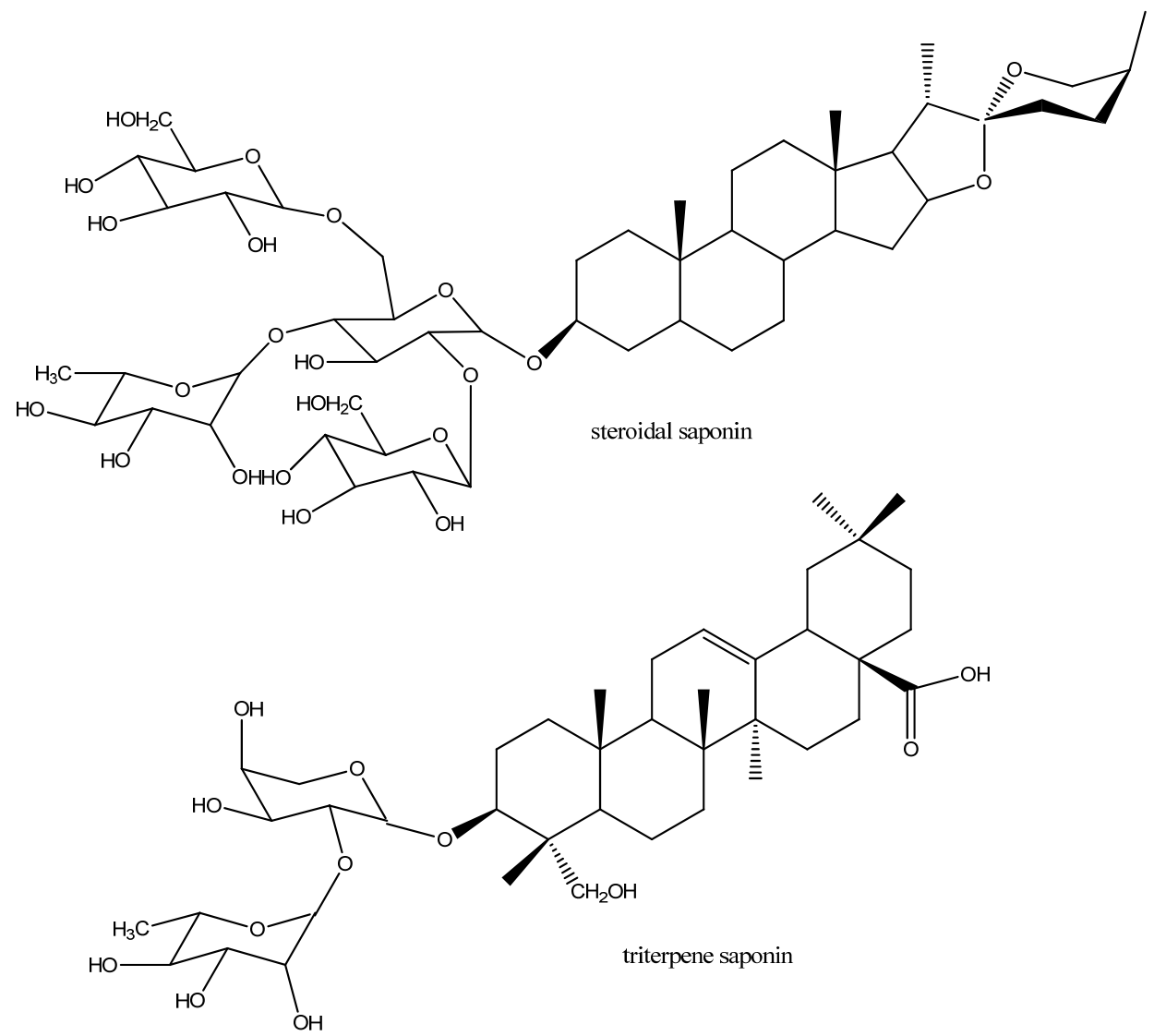




\subsubsection{Nervous System}

Multicellular parasites have a nervous system with a number of important neurotransmitter/ neuroreceptor systems, such as acetylcholine (ACh) and ACh-receptors (AChR). If the ACh-receptors, which control muscular activity, are inhibited or overstimulated, muscular paralysis can occur. This also happens if sodium and potassium channels are either blocked or stimulated, because ion signalling is essential in neuronal activity [17]. Muscular arrest can lead to direct death or in case of worms which are attached to the intestinal gut walls, they no longer can stick to the walls and are easily removed with the faeces after laxative treatment. The problem is to find a dose which affects the parasite but which is still not toxic for the patient. Cestodes and tapeworms which inhabit the intestine and not internal organs are easier to treat because any neurotoxic drug taken orally will affect them. The best compound would affect the worms but would not be absorbed by the intestinal cells.

Alkaloids, a class with more than 21,000 compounds which occur in almost all plant families, are infamous for their neurotoxic properties [9,10,17]. Many of them are agonists or antagonists at neuroreceptors and/or ion channels [10,17]. They provide interesting candidates for anthelmintic drugs.

\subsection{Anti-malaria Drugs}

Human malaria is caused by unicellular sporozoa (Apicomplexa) of the genus Plasmodium, which are transmitted by various mosquito vectors (Table 1). More than 250 million people are infected and more than a million deaths (mostly among children) are been recorded annually. The first drugs to treat malaria came from Cinchona officinalis and related Cinchona species (Rubiaceae) which naturally occur in Central and South America. Extracts from Cinchona bark contain quinoline alkaloids, such as quinine, quinidine, cinchonine, and cinchonidine (administered as "Quinimax" in malaria therapy). It was especially the bitter-tasting quinine (Figure 4) which could be used to treat the blood stages of Plasmodium [1,18]. Quinine served as a lead structure for the synthesis of several antimalarial drugs such as chloroquine, mefloquine, pyrimethamine, proguanil, atovaquone (sold together with proguanil as "Malarone"), or primaquine. Quinine (alone or in combination with doxocycline, tetracycline or clindamycin) is still used today to treat acute cases of severe $P$. falciparum infections. Over the years Plasmodium (especially P. falciparum causing tropical malaria) has become resistant against many of the synthetic drugs. Among the mechanisms of drug resistance an enhanced expression of $\mathrm{ABC}$ transporters has been reported which can pump out any drug in an ATP dependent fashion that has entered the parasite [19].

A breakthrough for the development of antimalarial drugs was the identification of the sesquiterpene artemisinin from Artemisia annua (Asteraceae), which can even kill multidrug resistant strains of $P$. falciparum [18,20]. Several semisynthetic derivatives of artemisinin (e.g., the water soluble artesunate) have been developed which are in clinical practice today [21] (Figure 4). A. annua is an old medicinal plant, occurring from the Mediterranean, all over Asia to China, where this plant is used in TCM.

Among medicinal plants from all over the world, more than 1,200 have been used (at least at one stage) to treat malaria and fever. However, clinical trials are mostly missing [18]. Quite a large number of plants have been identified which produce natural products with significant antimalarial activity. An 
$\mathrm{IC}_{50}$ of less than $11 \mu \mathrm{M}$ in $P$. falciparum usually indicates that a substance could be interesting for further drug development. Natural products with antimalarial activity have been identified among widely distributed phenolics (ellagic acid, epigallocatechin gallate, flavonoids, xanthones, coumarins, curcumin), naphthopyrones, quinones, widely distributed terpenoids (iridoids, sesquiterpenes, diterpenes, triterpenes), quassinoids, cucurbitacins (common in Cucurbitaceae), alkaloids (indolizidine, indole, isoquinoline), polyacetylenes [18,22-34].

Figure 4. Examples of anti-malarial secondary metabolites. Artesunate is a semisynthetic derivative of artimisinine.
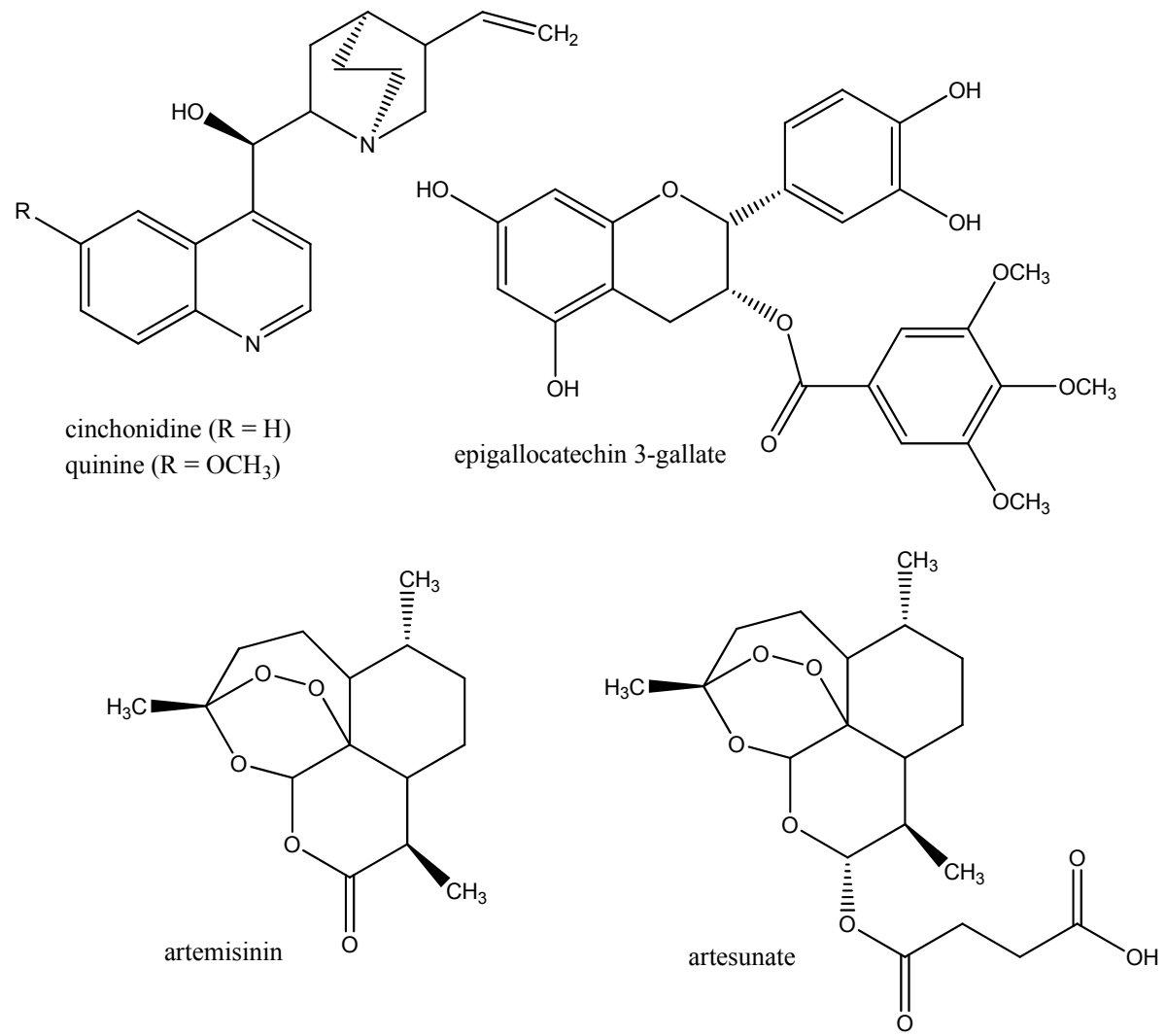

Medicinal plants usually contain complex mixtures consisting of several classes of secondary metabolites. It has been postulated that the combinations found in these extracts exhibit synergistic interaction [16]. If epigallocatechin 3-gallate (EGCG), a typical polyphenol of green tea, is combined with the saponin digitonin, a synergistic reduction of motility and survival of Plasmodium berghei has been recorded [28]. Digitonin may facilitate the uptake of the polar EGCG. It might thus be a good strategy to look for synergistic combination partners in traditional medicines instead of focussing on single molecules $[35,36]$.

\subsection{Drugs against Trypanosomes (Trypanosoma, Leishmania)}

\subsubsection{Trypanomiasis}

Trypanosomes are widely distributed blood parasites of animals. Humans are infected by $T$. brucei gambiense and $T$. b. rodesiense causing sleeping sickness or Human African trypanosomiasis (HAT) 
(Table 1). T. b. brucei affects cattle and causes Nagana. T. b. brucei is often used in screening assays because this parasite does not infect humans and thus is of no health risk for the researcher. HAT and Nagana are transmitted by tsetse flies (Glossina spp.). HAT is restricted to tropical Africa where more than 60 million people are at risk of becoming infected. Vector control programs and improved public health control have reduced the number of infections from 0.5 million to approximately 50,000 to 70,000 patients, with 17,000 new infections per year $[5,37,38]$.

Current chemotherapy of HAT is based on synthetic drugs developed more than 80 years ago, such as pentamidine and suramin. Whereas pentamidine binds to DNA, suramin is supposed to inhibit several glycolytic enzymes in trypanosomes. A derivative of pentamidine, pafuramidine (DB75) has clinically been tested recently. Later developed drugs include melarsoprol and eflornithine, the latter of which was registered in 1990. Eflornithine inhibits ornithine decarboxylase, which leads to a decrease of polyamine and of trypanothione, a unique antioxidant thiol compound of Trypanosoma and Leishmania. Eflornithine has recently been applied in combination with nifurtimox or melarsoprol. The number of chemotherapeutic drugs against HAT is very small and all of them exhibit severe side effects [5,37]. Furthermore, some trypanosomal strains have already become resistant to them, so that new drugs are urgently required.

A number of medicinal plants and secondary metabolites isolated from them have been screened for anti-trypanosomal activity [13,27,37,39-46]. Active natural products include several groups of alkaloids, phenolics, saponins, cardiac glycosides, other terpenoids, and polyacetylenes (common in Apiaceae, Asteraceae and Araliaceae). Although some natural products are active in the submicromolar range and show good selectivity, only few have been studied in vivo in an animal model. None of these results have been translated into clinical practice.

The mode of action of some drugs with anti-trypanosomal activities has been explored. A major target is glycolysis as blood forms can only gain energy by converting glucose to pyruvate or glycerol [38]. The enzymes responsible for the conversion of glucose to 3-phoshoglycerate and glycerol are found in a special compartment, the glycosome. If these enzymes are inhibited, trypanosomes will die.

Trypanosomes lack catalase and glutathione peroxidases but have evolved a unique system with trypanothione to detoxify hydroperoxide. Trypanothione is built from two molecules of glutathione and one molecule of spermidine (Figure 5). Inactivation of the enzymes of trypanothione, spermidine or glutathione biosynthesis or of trypanothione directly will lead to death of the parasite [38]. The synthetic drug eflornithine (see above) inhibits ornithine decarboxylase which is important for spermidine biosynthesis. It is likely that secondary metabolites which can bind to the SH-group of trypanothione exhibit anti-trypanosomal activity. This has been shown for polyacetylenes which carry a reactive triple bond that can easily alkylate $\mathrm{SH}$ groups; e.g., the polyacetylene Carlina oxide from Carlina acaulis (Asteraceae) (Figure 5) and polyacetylenes from ginseng (Panax ginseng) have significant cytotoxic activity against $T$. b. brucei but are hardly toxic to human cells $[47,48]$.

Trypanosomes have a single large mitochondrion, the kinetoplast, which contains several interlocked small $(1 \mathrm{~kb})$ and large $(23 \mathrm{~kb})$ circular mtDNA molecules (kDNA). Natural products which intercalate DNA target the sensitive kDNA. This has been shown in a comparative study with different groups of natural products [13,42]. Alkaloids which intercalate DNA such as berberine and sanguinarine exhibited $\mathrm{IC}_{50}$ values in the micromolar range [13]. Sanguinarine is also an inhibitor of microtubule formation [14]. 
Figure 5. Reduced and oxidised form of trypanothione and carlina oxide which can block the SH-groups of trypanothione.
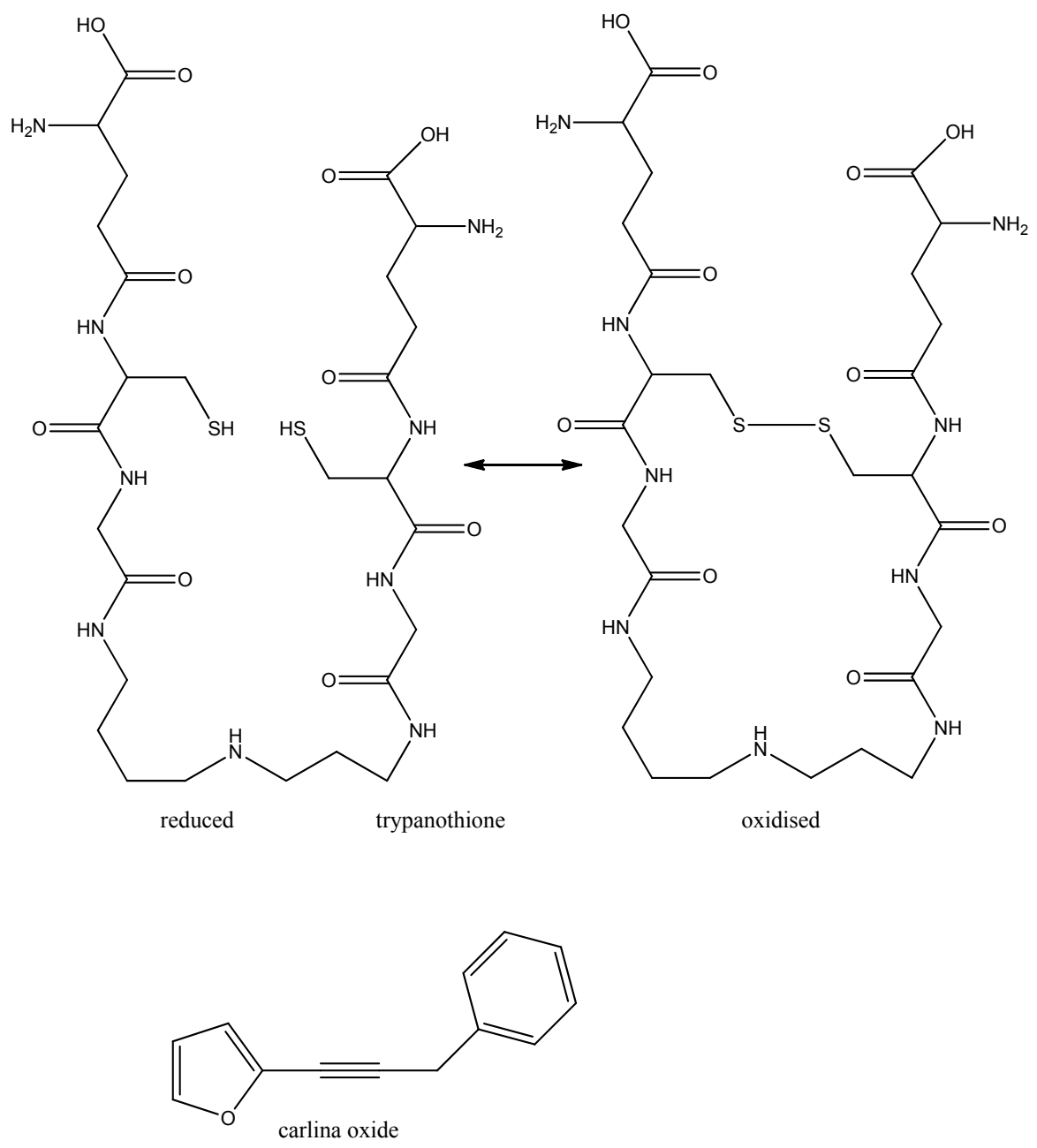

Another target is DNA topoisomerase I; camptothecin, a known inhibitor of DNA Topo I also inhibits $T$. brucei with an $\mathrm{IC}_{50}$ of $1.5 \mu \mathrm{M}$ [49]. The aporphine alkaloid dicentrine which is present in Papaveraceae and Lauraceae inhibits DNA Topo II and is active against trypanosomes [38,39]. Inhibitors of farnesyl transferase and tubulin polymerisation (e.g., vinblastine, sanguinarine) have substantial anti-trypanosomal activities [50].

\subsubsection{Chagas Disease}

Infections with Trypanosoma cruzi cause Chagas disease on the American continent. These parasites are transmitted by triatomine bugs but also by blood transfusion, organ transplantation or contaminated food or drinks (Table 1). More than 28 million people are at risk, 15 million are infected and about 12,500 humans die annually from T. cruzi infections [5]. Patients with Chagas disease are treated with benznidazole, and nifurtimox, and both drugs exhibit severe side effects. Other drugs include protease $x$ trans-sialase inhibitors and antagonists of ergosterol biosynthesis [5]. It is likely that many of the secondary metabolites, which have been tested against $T$. brucei [13,42] also affect T. cruzi [5]. 


\subsubsection{Leishmaniasis}

Leishmaniasis is caused by protozoan parasites of the genus Leishmania (Table 1) which invade macrophages of host organisms. A distinction is made between cutaneous, mucocutaneous, visceral and diffuse leishmaniasis, of which visceral leishmaniasis is a fatal disease causing approximately 60,000 death per year [51]. Leishmaniasis and HIV infections often co-occur and these patients usually have a poor prognosis. Patients are treated with the synthetic drugs stibogluconate, meglumine and pentamidine (developed 70 years ago), which have severe side effects and fail to work in North Bihar (India) [5,52]. Also the macrolide antibiotic amphotericin B has been employed, which can also be toxic for patients. New developments include the anticancer drug miltefosine, the aminoglycoside antibiotic paronomycin, and the 8-aminoquinoline sitamaquine [51]. Among natural products, berberine (which occurs in many TCM plants) had promising anti-leishmanial activities [5,52].

It is relatively easy to cultivate the promastigote form (which lives in the insect) axenically and to determine the cytotoxic effects of extracts or isolated compounds either by counting the parasites, or MTT or Alamar Blue photometric assays. More complicated is the analysis of the less susceptible amastigote forms in macrophages but these data are more realistic than those obtained from promastigote parasites. Transgenic amastigote forms which express reporter genes such as GFP have facilitated the screening $[51,53]$.

A number of natural products have already been screened. Among natural products from marine sources cyclic peptides, various flavonoids, chalcones, lignans, coumarins, iridoids, monoterpenes, saponins, toxoids, curcumin, quinoline alkaloids, and polyketides exhibit interesting anti-leishmanial activities [27,51,52]. Active flavanones and flavonoids were reported from Baccharis retusa (Asteraceae) and Kalanchoe pinnata (Crassulaceae) [51].

\subsection{Drugs against Trichomonas Vaginalis}

Trichonomiasis is caused by Trichomonas vaginalis and constitutes a common sexually-transmitted protozoan infection (Table 1). It mostly affects women and to minor degree men; about 170 million people are infected worldwide. It is often associated with HIV and cervical cancer [54]. Standard chemotherapy includes 5-nitroimidazoles, such as metronidazole and tinidazole. Because some of the Trichomonas strains have become resistant to the standard drugs, new chemicals are needed. Natural products have been analysed as an alternative and several alkaloids (e.g., berberine), dibenzofurans, anthraquinones, polyacetylenes, saponins, and diterpenes [54].

\subsection{Drugs against Worms (Nematoda, Cestoda, Trematoda)}

As illustrated in Table 1, a large diversity of worms belonging to different classes of invertebrates (Nematoda, Cestoda, Trematoda) can parasitize humans. Especially lymphatic filariasis, onchocerciasis, loaisis, schistosomiasis and other helminth-mediated diseases affect several million humans. It has been estimated that probably two billion humans (28\% of mankind) are infected by at least one species of helminth parasite at some stage of life $[55,56]$. The prevalence can be much higher in subtropical and tropical developing countries with poor hygiene and limited access to expensive medications. 
A number of in vitro and in vivo assays for anti-filarial and anti-helminthic screening have been developed, in which motility and viability are evaluated [56]. But because of the multitude of parasites involved adequate experimental systems are not available for every relevant parasite or relevant life stage.

Lymphatic filariasis is currently being treated with diethylcarbamazine (DEC) and ivermectin or in combination with albendazole [55]. New drugs are urgently required in order to treat drug resistant filariasis. A number of plants from traditional medicine, including plants from Ayurvedic and Chinese medicine have already been screened and a number of promising drugs or natural products could be identified [56,57]. Streblus asper (Moraceae) has proven anti-filarial activity both in vitro and in vivo and has been tested clinically in India [58]. The cardiac glycosides asperoside and strebloside appear to be the active components [59].

Onchocerciasis is treated with ivermectin in combination with albendazole whereas none is known for dracunculiasis [55]. The number of plants tested against onchocerciasis and dracunculiasis is much smaller than for filariasis, but a few African plants have been recorded [56,60]. In most studies only extracts from medicinal plants were screened and the profiles of secondary metabolites present were not established with modern phytochemical methods.

Schistosomiasis is treated with praziquantel alone or in combination with albendazole or ivermectin. Also oxamniquine, and antimalarial drugs, such as quinoline alkaloids and artemisinin and its derivatives have been employed [55]. Anthraquinones in Rheum palmatum and Rumex dentatus (Polygonaceae), phorbolesters from Jatropha curcas (Euphorbiaceae), and saponins in general exhibited molluscicidal activity against schistosomias vector snails Oncomelania, Biomphalaria and Bulinus [61]. Curcumin (Figure 6) and derivatives from Curcuma plants (Zingiberaceae) are parasiticidal in Schistosoma [27].

Parasitic intestinal helminths have been treated with vermicides and vermifuges. A synthetic drug is mebendazol that has been developed 40 years ago. It inhibits microtubules in the intestinal cells of worms, which leads to their degeneration and malnutrition. Mebendazol is only partly absorbed from human intestines and eliminated by first pass effects. Another synthetic anthelmintic is ivermectin. Important plants for this indication comprise Chenopodium ambrosioides (Amaranthaceae) and ascaridole which has been isolated from this plant [62] (Figure 6). Ascaridole is effective against hookworm infection, but mutagenic and poisonous $[9,10]$.

Another traditional herb is the fern Dryopteris filix-mas (Dryopteridaceae) which contains vermicidal phloroglucinols, such as aspidin, deaspidin, and filixic acid (syn. filicin) (Figure 6). They are active against intestinal cestodes and probably paralyze the worm's muscles [1]. Also this drug has considerable side effects for humans but filixic acid is used as an anthelmintic in veterinary praxis. Other paralyzing agents are the anthelmintic alkaloids pelletierine from Punica granatum (Lythraceae) and arecoline from Areca catechu (Arecaceae), which target acetylcholine receptors [9,10] (Figure 6).

Other anthelmintic plants include Artemisia maritima (with santonin), Artemisia abrotanum (Asteraceae) Zanthoxylum liebmannianum (Rutaceae), Thymus vulgaris (Lamiaceae), Millettia thonningii, Albizzia anthelmintica, Butea frondosa (Fabaceae), Embelia schimperi (Myrsinaceae), Teloxys graveolens (Amaranthaceae) and several others [56]. 
Figure 6. Secondary metabolites with anthelmintic properties.<smiles>COc1cc(/C=C/C(=O)/C=C(O)/C=C/c2ccc(O)c(OC)c2)ccc1O</smiles><smiles>CCCC(=O)C1=C(O)[C@@H](C)C(O)=C(Cc2c(O)c(C)c(OC)c(C(=O)CCC)c2O)C1=O</smiles>

\section{Conclusions}

In this review the relevant parasitic infections of humans and standard medications are tabulated. Several of the parasites have become resistant to chemotherapy, so alternatives are urgently required. Since vaccination has failed in most instances, the search for small molecules is still an option. For malaria and trypanosomiasis quite a number of medicinal plants and isolated natural products have already been tested, but for most of the other parasitic diseases such information is largely missing. Most of the antiparasitic properties of extracts and isolated natural products have been tested in vitro only. Translation of the in vitro research results into in vivo trials is urgently required. Furthermore, even if animal experiments were successful, we would need clinical trials of the new compounds alone or in combination with established parasiticidal drugs to prove their efficacy and safety. These developments are costly and it is presently difficult to attract the pharmaceutical industries into these fields for various reasons. 
TCM and other traditional medicine systems employ several thousand of medicinal plants; some of which have known antiparasitic properties. They offer a unique opportunity to identify natural products which could be potentially used to treat parasitic infections. The success story of artemisinin from Artemisia annua [2,20,63] can probably be repeated.

\section{Acknowledgements}

Thanks are due to Heidi Staudter for her help to obtain the relevant literature.

\section{References}

1. Van Wyk, B.-E.; Wink, M. Medicinal Plants of the World: An Illustrated Scientific Guide to Important Medicinal Plants and Their Uses; Timber Press: Portland, OR, USA, 2004.

2. Newman, D.J.; Cragg, G.M. Natural products as sources of new drugs over the last 25 years. J. Nat. Prod. 2007, 70, 461-477.

3. Wink, M. Functions and Biotechnology of Plant Secondary Metabolites; Wiley-Blackwell: Oxford, UK, 2010; Volume 39.

4. Peters, W.; Pasvol, G. Atlas of Tropical Medicine and Parasitology, 6th ed.; Mosby-Elsevier: Philadelphia, PA, USA, 2007.

5. Nussbaum, K.; Honek, J.; Cadmus, C.; Efferth, T. Trypanosomatid parasites causing neglected diseases. Curr. Med. Chem. 2007, 17, 1594-1617.

6. Wink, M. Production and application of phytochemicals from an agricultural perspective. In Phytochemistry and Agriculture, Proceedings Phytochemical Society Of Europe; van Beek, T.A., Breteler, H., Eds.; Oxford University Press: Oxford, UK, 1993; Volume 34, pp. 171-213.

7. Pohlit, A.M.; Rezende, A.R.; Lopez Baldin, E.L.; Peporine Lopes, N.; de Andrade Neto, V.F. Plant extracts, isolated phytochemicals, and plant-derived agents which are lethal to arthropod vectors of human tropical diseases_-A review. Planta Med. 2011, 77, 618-630.

8. Wink, M. Molecular modes of action of cytotoxic alkaloids- From DNA intercalation, spindle poisoning, topoisomerase inhibition to apoptosis and multiple drug resistance. Alkaloids 2007, 64, 1-48.

9. Wink, M.; van Wyk, B.E. Mind-Altering and Poisonous Plants of the World; Timber Press: Portland, OR, USA, 2008.

10. Wink, M.; Schimmer, O. Molecular modes of action of defensive secondary metabolites. In Functions and Biotechnology of Plant Secondary Metabolites; Wink, M., Ed.; Wiley-Blackwell: Oxford, UK; 2010; pp. 21-161.

11. Schmeller, T.; Latz-Brüning, B.; Wink, M. Biochemical activities of berberine, palmatine and sanguinarine mediating chemical defence against microorganisms and herbivores. Phytochemistry 1997, 44, 257-266.

12. Efferth, T.; Fu, Y.; Zu, Y.; Schwarz, G.; Newman, D.; Wink, M. Molecular target-guided tumor therapy with natural products derived from Traditional Chinese Medicine. Curr. Med. Chem. 2007, 14, 2024-2032.

13. Rosenkranz, V.; Wink, M. Alkaloids induce programmed cell death in bloodstream forms of trypanosomes (Trypanosoma b. brucei). Molecules 2008, 13, 2462-2473. 
14. Stanton, R.A.; Gernert, K.M.; Nettles, J.H.; Aneja, R. Drugs that target dynamic microtubules: A new molecular perspective. Med. Res. Rev. 2011, 31, 443-481.

15. Möller, M.; Wink, M. Characteristics of apoptosis induction by the alkaloid emetine in human tumor cell lines. Planta Med. 2007, 73, 1-8.

16. Wink, M. Evolutionary advantage and molecular modes of action of multi-component mixtures used in phytomedicine. Curr. Drug. Metab. 2008, 9, 996-1009.

17. Wink, M. Interference of alkaloids with neuroreceptors and ion channels. Stud. Nat. Prod. 2000, 21, 3-129.

18. Willcox, M. Improved traditional phytomedicines in current use for the clinical treatment of malaria. Planta Med. 2011, 77, 662-671.

19. Wink, M.; Ashour, M.; El-Readi, M.Z. Secondary metabolites inhibiting ABC transporters and reversing resistance of cancer cells and fungi to cytotoxic and antimicrobial agents. Front. Microbiol. 2012, 3, 1-15.

20. Efferth, T.; Herrmann, F.; Tahrani, A.; Wink, M. Cytotoxic activity towards cancer cells of secondary constituents derived from Artemisia annua L. in comparison to its designated active constituent artemisinin. Phytomedicine 2011, 18, 959-969.

21. Kuhn, T.; Wang, Y. Artemisinin-An innovative cornerstone for anti-malarial therapy. Prog. Drug Res. 2008, 66, 385-422.

22. Bero, J.; Quetin-Leclercq, J. Natural products published in 2009 from plants traditionally used to treat malaria. Planta Med. 2011, 77, 631-640.

23. Bero, J.; Frederich, M.; Quetin-Leclercq, J. Antimalarial compounds isolated from plants used in traditional medicine. J. Pharm. Pharmacol. 2009, 61, 1401-1433.

24. Bilia, A.R. Non-nitrogenous plant-derived constituents with antiplasmodial activity. Nat. Prod. Comm. 2006, 1, 1181-1204.

25. Caniato, T.; Puricelli, L. Review: Natural antimalarial agents (1995-2001). Crit. Rev. Plant Sci. 2003, 22, 79-105.

26. Fournet, A.; Munoz, V. Natural products as trypanocidal, antileishmanial and antimalarial drugs. Curr. Top. Med. Chem. 2002, 2, 1215-1238.

27. Haddad, M.; Sauvain, M.; Deharo, E. Curcuma as a parasiticidal agent: A review. Planta Med. 2011, 77, 672-678.

28. Hellmann, J.K.; Münter, S.; Wink, M.; Frischknecht, F. Synergistic and additive effects of epigallocatechin gallate and digitonin on Plasmodium sporozoite survival and motility. PLoS One 2010, 5, e8682.

29. Kaur, K.; Jain, M.; Kaur, T.; Jain, R. Antimalarials from nature. Bioorg. Med. Chem. 2009, 17, 3229-3256.

30. Nogueira, C.R.; Lopes, L.M.X. Antiplasmodial natural products. Molecules 2011, 16, 2146-2190.

31. Phillipson, J.D. Natural products as drugs. Trans. R. Soc. Trop. Med. Hyg. 1994, 88, 17-19.

32. Saxena, S.; Pant, N.; Jain, D.C.; Bhakuni, R.S. Antimalarial agents from plant sources. Curr. Sci. 2003, 85, 1314-1329.

33. Schwikkard, S.; van Heerden, F.R. Antimalarial activity of plant metabolites. Nat. Prod. Rep. 2003, 19, 675-692. 
34. Wright, C.W. Plant derived antimalarial agents: new leads and challenges. Phytochem. Rev. 2005, $4,55-61$.

35. Eid, S.Y.; El-Readi, M.Z.; Wink, M. Digitonin synergistically enhances the cytotoxicity of plant secondary metabolites in cancer cells. Phytomedicine 2012, doi:10.1016/j.phymed.2012.09.002.

36. Eid, S.Y.; El-Readi, M.Z.; Wink, M. Synergism of three-drug combinations of sanguinarine and other plant secondary metabolites with digitonin and doxorubicin in multi-drug resistant cancer cells. Phytomedicine 2012, in press.

37. Gehrig, S.; Efferth, T. Development of drug resistance in Trypanosoma brucei rhodesiense and Trypanosoma brucei gambiense. Treatment of human African trypanosomiasis with natural products. Int. J. Mol. Med. 2008, 22, 411-419.

38. Hannaert, V. Sleeping sickness pathogen (Trypanosoma brucei) and natural products: Therapeutic targets and screening systems. Planta Med. 2011, 77, 586-597.

39. Hoet, S.; Opperdoes, F.; Brun, R.; Quetin-Leclercq, J. Natural products active against African trypanosomes: a step towards new drugs. Nat. Prod. Rep. 2004, 21, 353-364.

40. Hoet, S.; Opperdoes, F.; Brun, R.; Adjakidje, V.; Quetin-Leclercq, J. In vitro antitrypanosomal activity of ethnopharmacologically selected Beninese plants. J. Ethnopharmacol. 2004, 91, 37-42.

41. Salem, M.M.; Werbovetz, K.A. Natural products from plants as drug candidates and lead compounds against leishmaniasis and trypanosomiasis. Curr. Med. Chem. 2006, 13, 2571-2598.

42. Merschjohann, K.; Sporer, F.; Steverding, D.; Wink, M. In vitro effect of alkaloids on bloodstream forms of Trypanosoma brucei and T. congolense. Planta Med. 2001, 67, 623-627.

43. Nibret, E.; Ashour, M.; Rubanza, C.D.; Wink, M. Antitrypanosomal and cytotoxic activities of some Tanzanian medicinal plants. Phytother. Res. 2010, 24, 45-47.

44. Nibret, E.; Sporer, F.; Asres, K.; Wink, M. Antitrypanosomal and cytotoxic activities of pyrrolizidine alkaloid producing plants of Ethiopia. J. Pharm. Pharmacol. 2009, 61, 801-808.

45. Nibret, E.; Wink, M. Chemical composition of essential oils from Hagenia abyssinica, Leonotis ocymifolia and Moringa stenopetala and structure activity relationships of isolated terpenoids in trypanosomes (Trypanosoma b. brucei) and human leucaemia cells (HL-60). Phytomedicine 2010, 17, 911-920.

46. Nibret, E.; Wink, M. In vitro antitrypanosomal and cytotoxic activities of four Artemisia species (Asteraceae) from Ethiopia. Phytomedicine 2010, 17, 369-374.

47. Herrmann, F.; Hamoud, R.; Sporer, F.; Tahrani, A.; Wink, M. Carlina oxide- a natural polyacetylene from Carlina acaulis (Asteraceae) with potent antitrypanosomal and antimicrobial properties. Planta Med. 2011, 77, 1905-1911.

48. Herrmann, F.; Tahrani, A.; Wink, M. Antitrypanosomal properties of Panax ginseng CA MeyerNew possibilities for a remarkable traditional drug! Phytother. Res. 2012, doi:10.1002/ptr.4692.

49. Bodley, A.L.; Shapiro, T.A. Molecular and cytotoxic effects of camptothecin, a topoisomerase I inhibitor, on trypanosomes and Leishmania. Proc. Natl. Acad. Sci. USA 1995, 92, 3726-3730.

50. Ochola, D.O.; Prichard, R.K.; Lubega, C.W. Classical ligands bind tubulin of trypanosomes and inhibit their growth in vitro. J. Parasitol. 2002, 88, 600-604.

51. Tempone, A.G.; de Oliveira, C.M.; Berlinck, R.G.S. Current approaches to discover marine antileishmanial natural products. Planta Med. 2011, 77, 572-585. 
52. Polonio, T.; Efferth, T. Leishmaniasis: Drug resistance and natural products (review). Int. J. Mol. Med. 2008, 22, 277-286.

53. Dube, A.; Gupta, R.; Singh, N. Reporter genes facilitating discovery of drugs targeting protozoan parasites. Trends Parasitol. 2009, 25, 432-439.

54. Gehrig, S.; Efferth, T. Development of drug resistance in Trichomonas vaginalis and its overcoming with natural products. Open Bioact. Comp. J. 2009, 2, 21-28.

55. Müllner, A.; Helfer, A.; Kotlyar, B.; Oswald, J.; Efferth, T. Chemistry and pharmacology of neglected helminthic diseases. Curr. Med. Chem. 2011, 18, 767-789.

56. Murthy, P.K.; Joseph, S.K.; Murthy, P.S.R. Plant products in the treatment and control of filariasis and other helminth infections and assay systems for antifilarial/anthelminthic activity. Planta Med. 2011, 77, 647-661.

57. Comley, J.C. New antifilaricicidal leads from plant? Trop. Med. Parasitol. 1990, 41, 1-9.

58. Singh, N.P.; Singh, V.K. Streblus asper-An ancient Indian drug for the cure of filariasis. Acta Bot. Indica 1987, 15, 108-109.

59. Chatterjee, R.K.; Fatma, N.; Murthy, P.K.; Sinha, P.; Kulreshtha, D.K.; Dhawan, B.N. Macrofilaricidal activity of the stem bark of Streblus asper and its major active constituents. Drug Dev. Res. 1992, 26, 67-78.

60. Ibrahim, M.A.; Nwude, N.; Ogunsui, R.A.; Aliu, Y.O. Screening of West African plants for anthelmintic activity. ILCA Bull. 1984, 17, 19-23.

61. Liu, L.; Sporer, F.; Wink, M.; Jourdane, J.; Hennig, R.; Li, Y.L.; Ruppel, A. Anthraquinones in Rheum palmatum and Rumex dentatus (Polygonaceae) and phorbolesters from Jatropha curcas (Euphorbiaceae) with molluscicidal activity against schistosomias vector snails Oncomelania, Biomphalaria and Bulinus. Trop. Med. Intl. Health 1997, 2, 179-188.

62. Kliks, M.M. Studies on the traditional herb anthelmintic Chenopodium ambrosioides L. Ethnopharmacological evaluation and clinical field trials. Soc. Sci. Med. 1985, 21, 16-21.

63. Mueller, M.S.; Runyambo, S.; Wagner, I. Randomized controlled trial of a traditional preparation of Artemisia annua L. (Annual Wormwood) in the treatment of malaria. Trans. R. Soc. Trop. Med. Hyg. 2004, 98, 318-321.

(C) 2012 by the authors; licensee MDPI, Basel, Switzerland. This article is an open access article distributed under the terms and conditions of the Creative Commons Attribution license (http://creativecommons.org/licenses/by/3.0/). 